Marquette University

e-Publications@Marquette

Nursing Faculty Research and Publications

Nursing, College of

$1-1-2015$

Factors Influencing Self-care Behaviors of African Americans with Heart Failure: A Photovoice Project

Aimee Woda

Marquette University

Ruth Belknap

Marquette University, ruth.belknap@marquette.edu

Kristin Haglund

Marquette University, kristin.haglund@marquette.edu

Margaret Sebern

Marquette University, margaret.sebern@marquette.edu

Ashley Lawrence

Marquette University

Accepted version. Heart \& Lung, Vol. 44 (January-February 2015): 33-38. DOI. (c) 2015 Elsevier Inc. Used with permission. 


\title{
Factors Influencing Self-Care Behaviors of African Americans With Heart Failure: A Photovoice Project
}

\author{
Aimee Woda \\ College of Nursing, Marquette University \\ Milwaukee, WI \\ Ruth Ann Belknap \\ College of Nursing, Marquette University \\ Milwaukee, WI \\ Kristin Haglund \\ College of Nursing, Marquette University \\ Milwaukee, WI \\ Margaret Sebern \\ College of Nursing, Marquette University \\ Milwaukee, WI \\ Ashley Lawrence \\ Aurora St. Luke's Medical Center, \\ Milwaukee, WI
}


NOT THE PUBLISHED VERSION; this is the author's final, peer-reviewed manuscript. The published version may be accessed by following the link in the citation at the bottom of the page.

\begin{abstract}
Objectives: The purpose of this study was to understand the influences of heart failure (HF) self-care among low income, African Americans.
\end{abstract}

Background: Compared to all other racial groups, African Americans have the highest risk of developing HF, coupled with high mortality and morbidity rates.

Methods: Using the photovoice method, participants related important lifestyle factors through photography. The participants and researcher met for reflection and discussion $2 \mathrm{~h}$ per week for six weeks.

Results: Four themes emerged: family support gives me the push I need, social interaction lifts me up, improving my mind to lift depression can improve my heart, and it is important but challenging to follow the HF diet. Conclusion: The findings from this study may assist policy makers, health care professionals, patients, and support systems in understanding the complexity of engaging in HF self-care. This understanding may lead to the development of appropriate patient-centered assessments and interventions.

Keywords: Heart failure; Self-care; African American; Photovoice; Barriers

Heart failure (HF) affects approximately 5.1 million people in the United States. Heart failure is most common in people 65 and older, and is the number one reason older people are hospitalized. $\underline{1}, \underline{2}$ and $\underline{3}$ The prevalence of HF is projected to increase $25 \%$ in the next 15 years, yielding be an estimated 6.3 million people living with HF by 2030.4 Heart failure is a chronic, complex syndrome that leads to high health care utilization and higher costs for care. In 2010 the estimated direct and indirect costs for the treatment of HF in the United States were $\$ 39.2$ billion, compared to $\$ 29$ billion in 2006.5 Heart failure is a lifelimiting condition that results in death within five years of diagnosis for $50 \%$ of patients. ${ }^{6}$ After HF is diagnosed, the survival rate is lower in men than in women; however, fewer than $15 \%$ of women survive longer than $8-12$ years. $\underline{1}$ and $\underline{2}$ Approximately 300,000 deaths each year are due to HF. $\underline{1}$ and $\underline{2}$

A significant health disparity is evident when considering HF among African Americans compared to other racial and ethnic populations in the United States. African Americans have the overall highest risk of developing HF (4.6\%), followed by Hispanics (3.5\%), and Caucasians (2.4\%). $\underline{7}$ and $\underline{8}$ Heart failure diagnosis at a younger age is more common among African Americans than Caucasians. $\underline{z}$ and $\underline{q}$ Furthermore, African Americans are more likely than individuals among other ethnic groups to suffer more severe forms of HF and have a more progressive disease trajectory. African Americans living with HF are hospitalized seven to eight times more often than

Heart \& Lung, Vol 44 (January/February 2015): pg. 33-38. DOI. This article is @ Elsevier and permission has been granted for this version to appear in e-Publications@Marquette. Elsevier does not grant permission for this article to be further copied/distributed or hosted elsewhere without the express permission from Elsevier. 
Caucasians. $\underline{7}$ and $\underline{9}$ Additionally, African Americans are more likely than Caucasians to die within five years of HF diagnosis, which explains the decrease in HF rates for African Americans over 75 years of age. $\underline{8}$

Previous investigators have identified sources for the disparate rates of HF among African American persons. Increased prevalence of hypertension (HTN), a primary cause of HF, is a serious concern among African Americans. $\underline{10}$ and $\underline{11}$ Chronic poverty and experiences of racism result in chronic elevations in cortisol, which in turn increases blood pressure. $\underline{12}$ and $\underline{13}$ African Americans also suffer from HTN at earlier ages ${ }^{6}$ and have other diseases that are more difficult to control than persons of other ethnicities. 14 A lack of insurance continues to be a considerable barrier in receiving health care, and this contributes to delayed diagnosis and persistence of untreated chronic conditions. As a group, African American adults have lower rates of insurance, higher rates of inadequate insurance, or no insurance compared to Caucasians. $\frac{11}{}$ Allostatic load, the body's attempt to adapt to stressors and maintain stability, $\underline{15}$ has been found to be higher in African Americans than Caucasians even after controlling for poverty. $\underline{16}$ Discrimination and poverty, therefore, also contribute to health disparities among African Americans. $\underline{16}$ and $\underline{17}$

Ethnic differences related to HF exist not only in health outcomes, but also in HF self-care. Heart failure self-care includes management of multiple medications, dietary and fluid restrictions, daily weight monitoring, symptom recognition and management, and a unique balance of rest and exercise. $\underline{18}$ Heart failure self-care is defined as a naturalistic decision-making process that involves the choice of behaviors that maintain physiological stability (self-care maintenance), the response to HF symptoms as they occur (self-care management), and the confidence (self-care confidence) to engage in each phase of self-care. $\underline{18}$ Many persons with HF find it challenging to learn and incorporate the necessary self-care behaviors into their daily lives. $\underline{19}$ For example, previous studies have identified that African Americans have difficulty adhering to the HF diet $\underline{20}, \underline{21}$ and $\underline{22}$ and taking their medications as prescribed. $\underline{23}$ The appropriate and consistent use of HF self-care can prevent hospitalization and improve health outcomes. $\underline{19}$ Helping patients improve their HF self-care is one way to decrease morbidity and early mortality. Interventions for vulnerable populations are strengthened when they are based on the participants'

Heart \& Lung, Vol 44 (January/February 2015): pg. 33-38. DOI. This article is @ Elsevier and permission has been granted for this version to appear in e-Publications@Marquette. Elsevier does not grant permission for this article to be further copied/distributed or hosted elsewhere without the express permission from Elsevier. 
understanding of the phenomenon and their self-identified needs. Therefore, the purpose of this study was to render a more complete understanding of the factors within ones living environment that influence low income, urban dwelling African Americans' engagement in HF self-care behaviors.

\section{Methods}

This study utilized a descriptive community-based participatory research design. The photovoice method was used for data collection and analysis. The photovoice method of research is built upon Freire's (1970/1973) theoretical literature on education for critical consciousness. Freire used picture drawings to enable people to think critically about social influences in their everyday life. In the photovoice method, the researcher provides cameras to people in the community so they may visually represent and communicate to others their experiences. ${ }^{24}$ In a fundamental way, participants serve as the experts on their own lives.

Photovoice is a means of exploration in which photographs provide visual records of what the participant perceives as a benefit or potential problem. The photographs offer visual documentation of what needs to be changed, strengthened, and/or maintained. This can be an environmental concern, health condition, or social issue. Taking photographs facilitates critical dialog (participant discussion and reflection) by helping participants express things that may otherwise be difficult to vocalize. Photovoice studies have revealed culturallyspecific information about the African American population's unique health conditions, needs, and assets. $\underline{25}, \underline{26}$ and $\underline{27}$ This study was approved by the university's institutional review board. The director of the housing authority granted permission to conduct the study within three buildings.

\section{Sample and setting}

This study was conducted in a large Midwestern city in which $17 \%$ of the residents have incomes at the federal poverty level, and $33 \%$ have incomes below the poverty line. $\frac{28}{\text { African Americans }}$ comprise $27 \%$ of the city's population and $6.5 \%$ of the state's

Heart \& Lung, Vol 44 (January/February 2015): pg. 33-38. DOI. This article is @ Elsevier and permission has been granted for this version to appear in e-Publications@Marquette. Elsevier does not grant permission for this article to be further copied/distributed or hosted elsewhere without the express permission from Elsevier. 
population. $\underline{29}$ Participants were recruited from three public housing buildings for low income and disabled adults over the age of 55 . The residents' average yearly income was less than $\$ 13,537$. These buildings were selected to facilitate participation of chronically ill older adults. Travel was not needed, and the onsite meeting room was familiar, safe, and convenient for the participants. Recruitment was coordinated with case managers employed by the housing authority. Case managers reviewed the onsite health records to identify individuals with a history of HF and discussed the study with these potential participants. The case manager provided names and contact information of interested residents to the primary investigator (PI) who visited residents in their apartments to explain the study. Those who wanted to participate completed the informed consent and demographic questionnaires during this visit. Ten residents participated. Residents were divided into three groups by building. There were two groups of 4 and one group of 2 .

\section{Photovoice procedure}

Three groups were conducted simultaneously, one at each site. Each group was conducted in the same manner following guidelines for photovoice projects. $\underline{30}$ Groups met for six, 2 h sessions. The PI drew from her experience on a previous photovoice study with minority participants to lead the sessions in this study. In the initial session, the PI provided education about safety, power relationships, ethics of taking photos, and how to obtain written consent. Written consent was required when photos were taken of individuals whose faces would be viewable. Prior to taking such photos, participants read off a laminated card that explained the purpose of the study and how the photograph would be used to potential photo subjects. If in agreement, the photo subjects signed a consent allowing the photo to be taken and used in a public display or in a published manuscript. Parental consent was obtained for anyone under the age of 18 . Participants were given digital cameras for use during the project. Cameras were returned at the end of the study. The PI gave instruction on camera use and photographic techniques. Weekly photo assignments instructed participants with the following prompts: photograph "images representing what makes you want to, or what makes it easy to take care of yourself and your HF"; "what makes it difficult for you to take

Heart \& Lung, Vol 44 (January/February 2015): pg. 33-38. DOI. This article is @ Elsevier and permission has been granted for this version to appear in e-Publications@Marquette. Elsevier does not grant permission for this article to be further copied/distributed or hosted elsewhere without the express permission from Elsevier. 
care of yourself and your HF"; and "anything else you want to express or feel is important and relates to how you take care of your HF." All photovoice sessions were audiotaped and transcribed verbatim by the PI and research assistant (RA).

At the second through fifth sessions, participants' photographs were downloaded onto the PI's computer and projected on a wall for group discussion. At the beginning of each discussion, the PI invited participants to discuss only what they were comfortable sharing. Initially, the SHOWeD questions were used as prompts to facilitate photo discussion ( $\underline{B o x} 1) . \underline{26}$ and $\underline{31}$ The purpose of the SHOWeD questions is to gather further information on an image and to identify potential solutions to the problems identified. $\underline{26}$ However, participants in the first session of the first group had difficulty applying the questions to the photographs taken. For example, when the first questions were posed ("What do you See here? What is really Happening here? And How does this relate to Our lives?"), participants expressed lack of understanding of the questions prompting the PI to modify the SHOWeD questions. The modified questions included, "What does this mean to you?" "How does this affect your health and your heart?" and, "Does this make it easier or more difficult for you to take care of your health and your heart?" The modified questions were instituted in the second session of the first group and were used in all sessions of the second and third groups. The PI, who was an experienced HF nurse, provided information regarding HF or HF selfcare when directly asked. Similarly, the PI interjected if discussion involving these topics consisted of incorrect information or misconceptions regarding HF and HF self-care. The American Heart Association HF guidelines were used as a resource when needed. $\underline{2}$

Box 1. SHOWeD acronym used for group discussion prompts.

SHOWeD is an acronym for.

What do you See here?

What is really Happening here?

How does this relate to Our lives?

Why does this situation, concern, or strength exist?

What can we Do about it?

Heart \& Lung, Vol 44 (January/February 2015): pg. 33-38. DOI. This article is @ Elsevier and permission has been granted for this version to appear in e-Publications@Marquette. Elsevier does not grant permission for this article to be further copied/distributed or hosted elsewhere without the express permission from Elsevier. 
After the fifth session, $4 \times 6$ prints of all photographs taken were developed. During the sixth session, printed photographs were spread out on a table allowing for final reflection, discussion, and organization into thematic categories. Participants were asked to group like photographs and to create a name expressing the theme of grouped pictures. This process occurred for participant groups 1, 2, and 3 . Beginning with group 2, after the group assigned topic names to their photographs, the previous groups' photographs were introduced. Group 2 was then able to combine their photographs with some of group one's themes or vice versa. At this point several of the photograph topics were changed. The same sequence of events occurred for group 3. All three groups had taken photographs of similar topics. Consensus occurred on all photo groupings except for the photographs related to depressive symptoms.

At the conclusion of this study, a photo show was developed. Photographs from all three sites were shown together. For the show, residents from each building selected photos they felt best represented their response to the photo assignments. The photos were enlarged and placed on a poster board with the associated themes. Three exhibitions of the photos occurred, one at each site. As part of the exhibition, the PI provided an educational presentation of the signs and symptoms, risk factors, and management of HF. The participants from the study were present during the presentation and shared their stories with the residents of the building.

\section{Data analysis}

Data analysis conducted by the PI and RA included data reduction, data display, and formulating conclusions. $\underline{\underline{32}}$ Data reduction involved multiple readings of the transcripts with the intention of identifying the facilitators and challenges of engaging in HF self-care. Passages of data were coded with topic codes written in the margins. Data was displayed in matrices to assist with the organization and analysis of the transcribed data. Matrices included the topic codes and corresponding direct quotes. The topic names identified by the participants were then compared to the themes that emerged from the matrices, resulting in four themes. Emerging patterns and themes

Heart \& Lung, Vol 44 (January/February 2015): pg. 33-38. DOI. This article is @ Elsevier and permission has been granted for this version to appear in e-Publications@Marquette. Elsevier does not grant permission for this article to be further copied/distributed or hosted elsewhere without the express permission from Elsevier. 
supported the participants' identified themes depicting their experiences.

Various methods were employed to ensure rigor. $\underline{33}$ The small, purposeful sample facilitated a deep exploration of HF self-care among older African American adults. Rich description of the results included participant quotes and photos. A detailed account of the procedures was included. Rich and detailed description allows the reader to determine the transferability of the methods and results to another population. The same procedures were followed in each group for recruitment, data collection and analysis demonstrating that the researchers systemically explored the topic and contributed to the dependability of the study. Member checking was used to ensure that participants felt that the themes identified by the researchers accurately depicted their experiences which contributed to credibility of the findings. The PI demonstrated reflexivity, the practice of overtly examining one's own biases and preconceptions, by seeking clarification and prompting explanation of members' comments during group sessions. The PI also discussed data, themes, and results with a team of expert qualitative nurse researchers who were expert in HF self-care and qualitative research. Establishment of transferability, dependability, credibility and reflexivity established the confirmability of the results.

\section{Results}

\section{Description of participants}

Three men and seven women living with HF participated in the study. Each participant lived alone in a one bedroom apartment in one of three public housing buildings. Demographic data and clinical characteristics were self-reported (see Table 1 and Table 2). Participants may have not reported all co-morbidities. For example, no participants identified having coronary artery disease or cardiomyopathy, which are commonly associated with HF. Four themes described participants' views regarding their engagement in HF selfcare, including: family support gives me the push I need, social interaction lifts me up, improving my mind to lift depression can

Heart \& Lung, Vol 44 (January/February 2015): pg. 33-38. DOI. This article is @ Elsevier and permission has been granted for this version to appear in e-Publications@Marquette. Elsevier does not grant permission for this article to be further copied/distributed or hosted elsewhere without the express permission from Elsevier. 
NOT THE PUBLISHED VERSION; this is the author's final, peer-reviewed manuscript. The published version may be accessed by following the link in the citation at the bottom of the page.

improve my heart, and it is important but challenging to follow the HF diet.

Table 1. Demographic and descriptive characteristics $(n=10) . \underline{a}$

\section{Characteristic}

Age

Length of years with HF $(n=8)$

Daily medications

Monthly medication costs
Mean (SD)

67.5 (5.7) years

Median (range)

8 (3.5) medications $8(2-14)$ medications

79.8 (150.4) dollars $25(0-500)$ dollars

data are self-reported. Data are collected at baseline. Length of years with HF $(n=8)$, as two participants did not know the length of diagnosis.

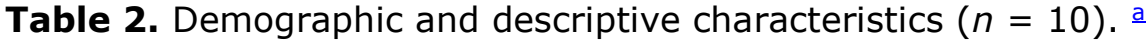

Characteristic

Gender

Female

Male

Marital status

Single

Divorced

Widowed

Monthly income

Not enough

Just enough

Self-reported co-morbidities

Cardiac arrhythmias

Chronic pulmonary disease

Depression

Diabetes

Hypertension

Peptic ulcer disease

NYHA Functional Classification

Class I

Class II

Class III

Class IV
Number

Percent

70.0

30.0

3

40.0

40.0

20.0

2

50.0

5

50.0

6

10.0

60.0

20.0

30.0

90.0

40.0

4

3

30.0

4

40.0

00.0

3
30.0

all data are self-reported. Data are collected at baseline. The New York Heart Association Functional Classification (NYHA) was taken from Committee for the New York Heart Association, 1994.

Heart \& Lung, Vol 44 (January/February 2015): pg. 33-38. DOI. This article is C Elsevier and permission has been granted for this version to appear in e-Publications@Marquette. Elsevier does not grant permission for this article to be further copied/distributed or hosted elsewhere without the express permission from Elsevier. 


\section{Family support gives me the push I need}

Participants commonly reported how support from others helped them engage in HF self-care. All but one of the participants reported their immediate family (brother, sister, children, and grandchildren) as the main source of instrumental, informational, and emotional support. Examples of instrumental support from family members included physical assistance such as: "She helps me clean"; "She takes me to church"; and, "She cooks me dinner." Family members were described as always being available. One participant stated, "I could call one of them and they would come get me, whatever I need."

Family members were also helpful in providing informational support, such as frequent reminders for medications and dietary restrictions: "She be on me"; "Remind me of my medications and the food that I am eating"; "My do's and don'ts of food and activity"; and, "She checks to see what I am cooking." One participant discussed Fig. S1, describing the type of support her daughter provides: "She visits every day, sometimes two or three times. She inspects the kitchen for food items I shouldn't have. She be on me, she helps me. This makes me want to do the right things. When she don't come around I am calling her because I need that push."

In addition to providing informational and instrumental support, family members also offered emotional support. Grandchildren were especially important to the female participants. While discussing Fig. S2, the same participant described this relationship: "My granddaughter puts a highlight in my life, especially when I am feeling down. She always makes me feel better and being with her takes away a lot of the stress. She gives me the push I need to do better."

\section{Social interaction lifts me up}

Several photographs of friends were taken. Companionship was described as playing cards (Fig. S3), bingo, watching television, or listening to music with friends. Spending time with friends was described as both uplifting and relaxing. All participants acknowledged that social interaction promoted conversation and laughter. One participant said, "If you're under depression, it relaxes you if you

Heart \& Lung, Vol 44 (January/February 2015): pg. 33-38. DOI. This article is @ Elsevier and permission has been granted for this version to appear in e-Publications@Marquette. Elsevier does not grant permission for this article to be further copied/distributed or hosted elsewhere without the express permission from Elsevier. 
around other people." Another said, "We laughed and talked, this relaxes you and you won't get so tense." Accessibility to friends was reported as beneficial: "It's good to talk to someone else and get their view point on some things"; "Being around somebody who is laughing and talking has helped me"; and, "You won't get so stressed out when you are around somebody." Time spent with peers "lifts you up" and "lifts your spirit."

\section{Improving my mind to lift depression can improve my heart}

Depressive symptoms were participants' primary reason for not taking medications, following prescribed diets, and/or participating in daily physical activity. None of the photographs depicted depressive symptoms. Twenty-eight photos were taken of things and activities that participants used to avoid or ameliorate their feelings of depression such as a radio, television, fish and plants in fish tanks, potted plants, books, and card playing. When discussing these photos, all participants said these activities relaxed them, eased their minds, and improved thinking. A male participant stated, "If you improve your mind, your heart can improve."

When participants felt depressed they reported, "I don't do anything"; this included not leaving their apartment or exercising. One participant said, "I don't come out the apartment when I'm depressed, I'm just there. I don't answer the phone or the door." Depressive symptoms influenced medication adherence and following diets: "Depressed people are not eating right and taking their pills." Another participant stated, "I can't eat, I don't want to eat." Several participants reported feeling cardiovascular effects: "When I'm depressed I feel like mine [heart] is just slowing down"; another participant added, "I'm slowing down and my heart's slowing me down." Another participant reported, "I feel so down until I think I need to go to the emergency room." for this version to appear in e-Publications@Marquette. Elsevier does not grant permission for this article to be further copied/distributed or hosted elsewhere without the express permission from Elsevier. 


\section{It is important but challenging to follow the heart failure diet}

Dietary challenges were identified while discussing photographs of fast food restaurants, vending machines, and canned vegetables. These photographs sparked conversation about environmental challenges the participants encountered while attempting to follow prescribed diets. Two residents discussed the cost of healthy food: "I can't afford to buy healthy food" and "Fried food is not good for you. I know that, but that's cheap." Others said they gave things up in order to afford the healthy choices, even when more expensive. Another participant offered, "I want to stay healthy and strong so I cut back on something and I get me some bananas, apples, grapefruits, and oranges." Several participants discussed the problems with having vending machines (see Fig. S4) in the building. One participant went on further to explain the temptation that the vending machines caused: "They don't have any diet stuff in the vending machine. I sit here all day looking at that machine. It [vending machine] is right here in my face. It's enticing to us. Eventually you find yourself getting something that you don't need."

All participants denied eating regularly at fast food restaurants, but they did discuss the ease of access to and temptation by fast food restaurants. One building was directly across the street from a fast food restaurant. Two buildings had fast food restaurants within walking distance. None of the buildings had a grocery store in the area. Participants reported that neighbors would walk to the restaurants and offer to return with food for them. Fast food was tempting because it was easier than cooking. One commented, "It's easy to order pizza." Another said, "[It's] cheap to get a hamburger." The majority expressed preference for home cooking and often shared meals with other residents. But several participants did report opting for fast food or something from the vending machine when tired or not feeling well.

An additional dietary barrier described was the free food provided each month to qualified, low-income residents from a local non-profit agency. These boxes were filled with canned foods, cereals, and other nonperishable processed food products. This was described as a constant struggle. They understood that they should avoid most

Heart \& Lung, Vol 44 (January/February 2015): pg. 33-38. DOI. This article is @ Elsevier and permission has been granted for this version to appear in e-Publications@Marquette. Elsevier does not grant permission for this article to be further copied/distributed or hosted elsewhere without the express permission from Elsevier. 
of this food, however, using this food helped save money. Due to the high salt content, most of the participants could use only half the food items in the box. Unused food items were given away.

Participants in one of the three groups took photographs of a failed vegetable garden. The discussion concerning these photographs focused on the stress and frustration associated with aspects of their immediate environment. The vegetable garden was planted and maintained by one of the residents in the group, and while it was intended to provide free healthy food to residents of the building, members of the community at large repeatedly burglarized the garden.

\section{Discussion}

Based on the findings from this study, several important influences on engaging in HF self-care behaviors were identified: family support gives me the push I need, social interaction lifts me up, improving my mind to lift depression can improve my heart, and it is important but challenging to follow the HF diet. Social support, which is the perception of support one receives from others in the environment, $\underline{34}$ was described as the primary reason for engaging in HF self-care. Although social support was not formally measured in the present study, verbal reports identified that immediate and extended family members were the primary sources of social sup-port, followed by friends and health care providers. Other researchers have also reported strong kinship ties among African American participants. 35 Perceived support from a significant other, family members, or friends has been shown to increase medication and dietary adherence. $\underline{35}$ and $\underline{36}$

Friendly companionship also positively influenced engaging in HF self-care for the present study participants. Participants described that friendly companionship evoked laughter, increased feelings of relaxation and happiness, provided distraction from worry and improved their moods. Being around others was identified as alleviating depressive symptoms. Having friends in the same building led participants to readily join activities in the community room, and ultimately increased their physical activity and healthy socialization. Friendly companionship has been shown to increase engagement in self-care behaviors in this study and in others. $\underline{20}, \underline{35}, \underline{37}$ and $\underline{38}$

Heart \& Lung, Vol 44 (January/February 2015): pg. 33-38. DOI. This article is @ Elsevier and permission has been granted for this version to appear in e-Publications@Marquette. Elsevier does not grant permission for this article to be further copied/distributed or hosted elsewhere without the express permission from Elsevier. 
In a meta-analysis, DiMatteo $\underline{39}$ found that functional support had a greater influence on self-care adherence than support based on marital status or household composition. In other words, strong, supportive, quality relationships may be more valuable than merely having an individual present, such as a spouse or another family member. The value of quality social support was visible among the participants in the present study; although each of the participants lived alone, all reported having strong social support from family members, friends, and health care professionals that provided informational, instrumental, and emotional support. Friendly companionship was accessible for these participants as they lived in close proximity to others who were similar to themselves. The case managers in the buildings promoted socialization among the residents by organizing group outings, bingo, and card games. Case managers also performed frequent assessments and followed up with appropriate interventions as needed. Social support that was provided to this vulnerable population was reported by participants as being essential to their ability to successfully engage in HF self-care.

Similar to findings from other studies, depressive symptoms and difficulty adhering to dietary restrictions were identified as challenges to engaging in HF self-care. $\underline{20}$ Participants in the present study reported that feeling depressed negatively impacted medication and dietary adherence. Participants explained that when they felt depressed, they secluded themselves from others. They also reported feeling fatigued and as if their hearts were slowing down. Similar to other studies, participants described depression as being detrimental to engaging in HF self-care. $\underline{40}, \underline{41}$ and $\underline{42}$ Although the participants in the present study identified the challenges of having depressive symptoms, many approaches to dealing with the symptoms were identified.

The amount of healthy versus non-healthy food products in near proximity to one's home has been shown to influence individuals' consumption of healthy and non-healthy food items. $\frac{43}{}$ This relationship was supported in the present study. Participants purchased food from the vending machines, went to fast food restaurants, and consumed the items from their free food box despite knowing they should avoid these items. Artinian et al $\underline{23}$ and Gary $\underline{20}$ also reported that low income participants relied heavily on canned food. Glanz et al $\underline{43}$ described this

Heart \& Lung, Vol 44 (January/February 2015): pg. 33-38. DOI. This article is @ Elsevier and permission has been granted for this version to appear in e-Publications@Marquette. Elsevier does not grant permission for this article to be further copied/distributed or hosted elsewhere without the express permission from Elsevier. 
problem as being caused by the general environment and is based on the distribution of food items.

\section{Recommendations for practice}

Findings from this study suggest that health care providers should focus on encouragement of positive behaviors, such as understanding dietary restrictions, obtaining social support, and ways to overcome depressive symptoms. In this study, participants engaged in HF self-care. The environment posed challenges that made it difficult to follow the recommended self-care behaviors despite their desire to do so. To understand how patients are managing their HF diet, it is important to ask how and where food is obtained. This question will help identify the typical foods consumed by patients and the choices they face when purchasing foods. Nurses can assist in identifying appropriate food sources if there is limited access to grocery stores or a limited budget. Other interventions may include teaching patients how to purchase and prepare less expensive meals that are enjoyable and meet dietary requirements. A strategy to avoid purchasing food from vending machines may be as simple as eating a healthy snack before going to areas of the building with vending machines. Planning meals ahead of time or cooking meals with other residents may decrease costs as well as temptation to go to fast food restaurants. Nurses must advocate for healthy food options for those who rely on government food subsidy programs and local food pantries. As indicated by the participants in this study, free food is often not healthy food. Political support for the federal Supplemental Nutrition Assistance Program (SNAP), commonly referred to as food stamps, is important. SNAP is one program that allows participants to choose healthier options. At the local level, nurses can work to change the quality of food distributed by food banks.

In this study support and companionship were important facilitators of HF self-care. To assess patients' support systems, health care professionals should assess household composition, patients' health needs and persons available to provide support and assistance. Encouraging family members and/or friends to attend medical appointments and to be included in the plan of care may result in additional support for patients. Inclusion of support persons in the

Heart \& Lung, Vol 44 (January/February 2015): pg. 33-38. DOI. This article is @ Elsevier and permission has been granted for this version to appear in e-Publications@Marquette. Elsevier does not grant permission for this article to be further copied/distributed or hosted elsewhere without the express permission from Elsevier. 
development of interventions, goals, and teaching sessions may provide additional benefits for patients.

Intermittent episodes of feeling depressed were described as the primary challenge to engaging in HF self-care. Health care providers should routinely assess patients with HF for depressive symptoms and advise as needed. Open discussions about depression may encourage patients to share such symptoms and lead to productive conversation. Interventions should focus on ways to alleviate or prevent depressive symptoms. Examples provided by participants included playing cards or bingo, exercising, and taking care of plants and pets.

Several study limitations were identified. Purposeful selection was limited to participants that self-identified as African American, had $\mathrm{HF}$, and were over the age of 55 . The study was not designed to be generalizable, but to render a more complete understanding of what influences HF self-care behaviors. Participants in this study had many support systems within their environment. Different and additional challenges may have been identified for individuals who do not live in public housing. Final collective analysis of all photographs did not occur with the entire group of participants. Such a discussion may have resulted in an alteration of themes.

\section{Conclusion}

These findings emphasize that the environment has an inherent and direct influence on HF self-care. For these participants, having friends and case managers within their residence promoted positive HF self-care. Although participants consistently described their personal strengths, other inescapable challenges continued to exist. It is likely that these challenges were not specific to African Americans, but are rather experienced by all those living in low income, urban settings. Because many of the challenges were specific to the participants' environmental surroundings, it is imperative that nurses take time to explore patient-specific challenges, individualized assessments, and develop patient-specific interventions. Future research studies are needed that focus on decreasing the immediate environmental barriers to following dietary restrictions; assessment of, and intervention for, depression; and inclusion of patient support systems within the plan of care.

Heart \& Lung, Vol 44 (January/February 2015): pg. 33-38. DOI. This article is @ Elsevier and permission has been granted for this version to appear in e-Publications@Marquette. Elsevier does not grant permission for this article to be further copied/distributed or hosted elsewhere without the express permission from Elsevier. 
NOT THE PUBLISHED VERSION; this is the author's final, peer-reviewed manuscript. The published version may be accessed by following the link in the citation at the bottom of the page.

\section{Supplementary data}

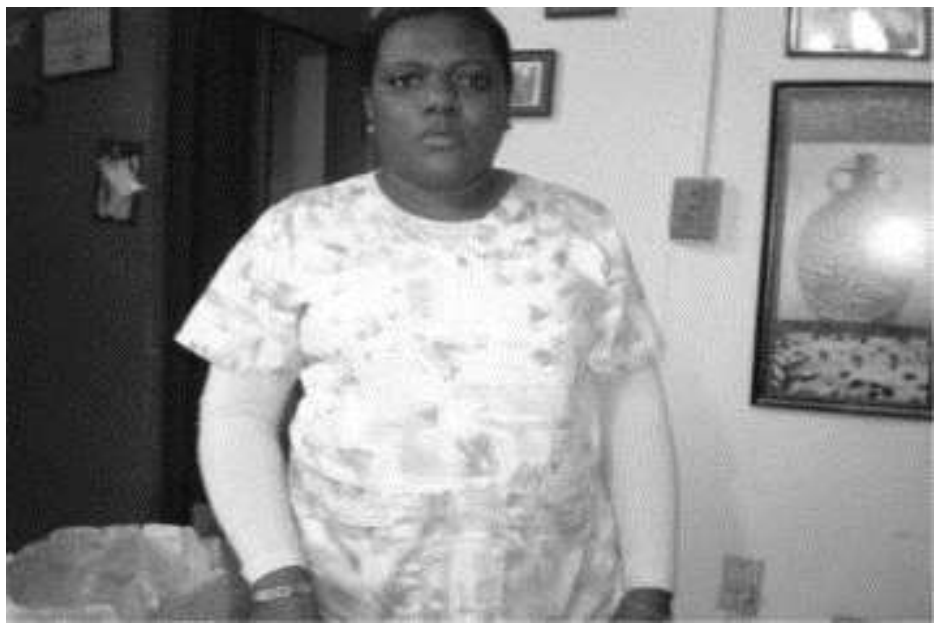

Fig. S1. Photograph of Daughter. Theme: Family support gives me the push I need.

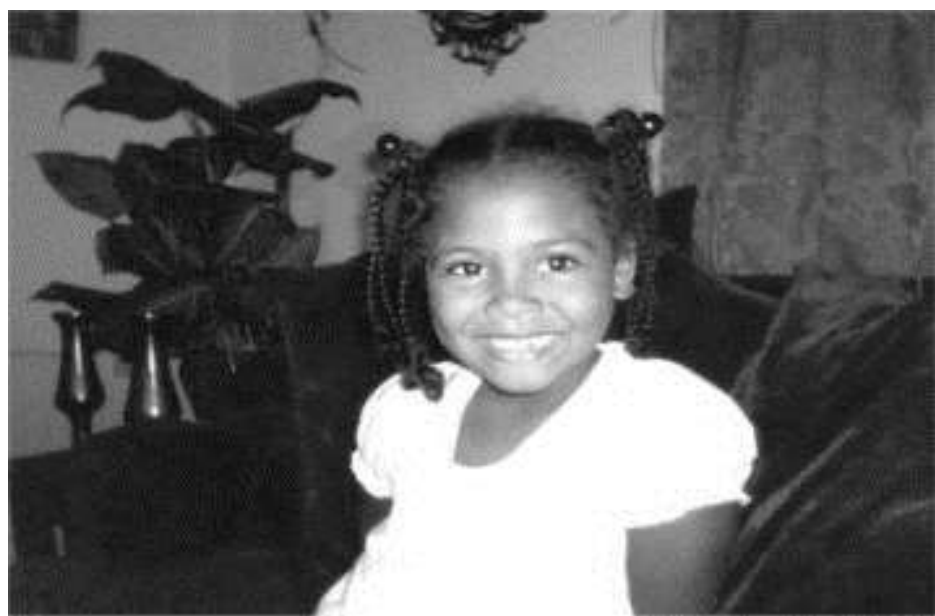

Fig. S2. Photograph of Granddaughter. Theme: Family support gives me the push I need 
NOT THE PUBLISHED VERSION; this is the author's final, peer-reviewed manuscript. The published version may be accessed by following the link in the citation at the bottom of the page.

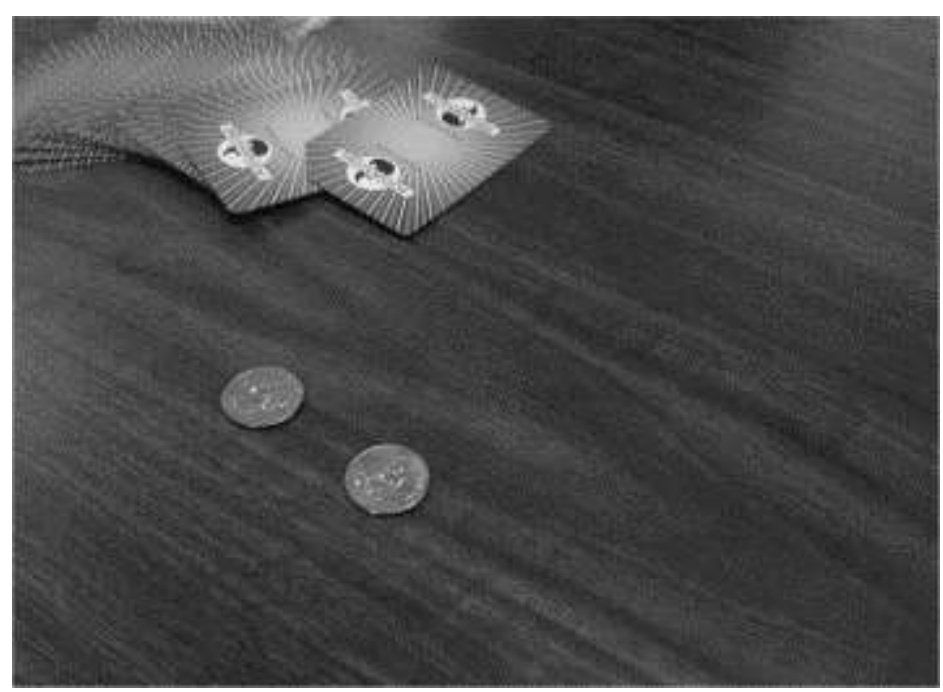

Fig. S3. Photograph of Cards. Theme: Social interaction lifts me up.

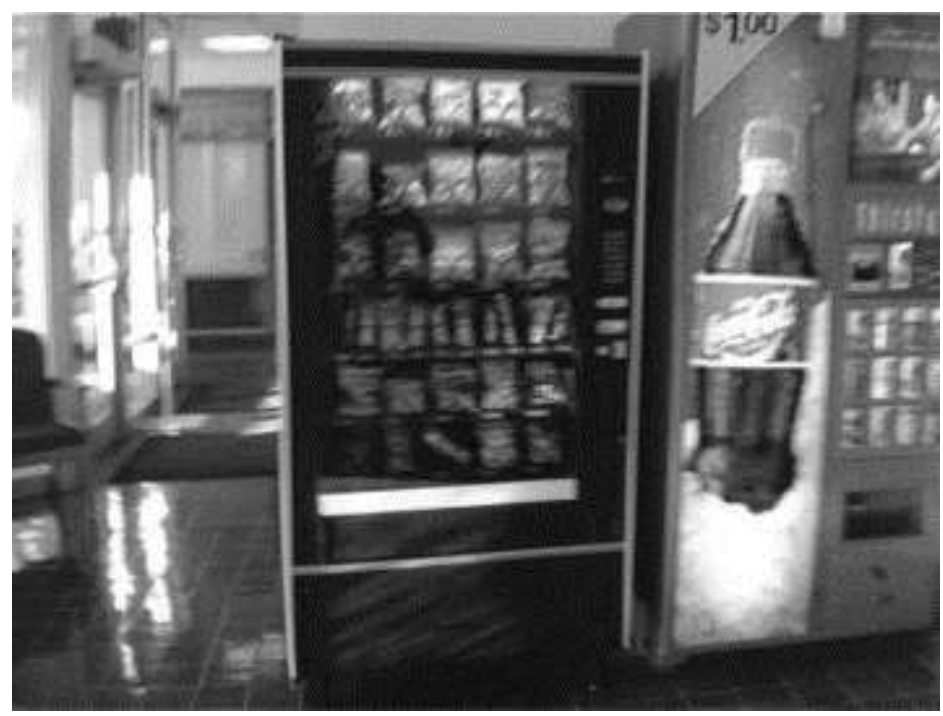

Fig. S4. Photograph of Vending Machines. Theme: It is important, but challenging, to follow the HF diet.

\section{References}

1 Incidence and Prevalence: 2006 Chart Book on Cardiovascular and Lung Diseases (Published 2006) National Heart Lung and Blood Institute [NHLBI] Website http://www.nhlbi.nih.gov/resources/doc/06a 1p chtbk.pdf Accessed 01.03 .14

2 What is Heart Failure? (Published 2012) National Heart Lung and Blood Institute [NHLBI] Website

Heart \& Lung, Vol 44 (January/February 2015): pg. 33-38. DOI. This article is @ Elsevier and permission has been granted for this version to appear in e-Publications@Marquette. Elsevier does not grant permission for this article to be further copied/distributed or hosted elsewhere without the express permission from Elsevier. 
NOT THE PUBLISHED VERSION; this is the author's final, peer-reviewed manuscript. The published version may be accessed by following the link in the citation at the bottom of the page.

http://www.nhlbi.nih.gov/health/dci/Diseases/Hf/HF WhatIs.htmll Accessed 01.03.14

$\underline{3}$ T. Thom, N. Hasse, W. Rosamond, et al. American Heart Association statistics committee and stroke statistics sub committee; Heart disease and stroke statistics - 2006 update. Circulation, 113 (6) (2006), pp. 85-151

4 P. Heidenreich, J. Trogdon, O. Khavjou, et al. Forecasting the future of cardiovascular disease in the United States: a policy statement form the American Heart Association. Circulation, 123 (2011), pp. 933-944

5 D. Lloyd-Jones, R. Adams, T. Brown, et al. Heart disease stroke statistics 2010 update. A report from the American Heart Association statistics committee. Circulation, 121 (2010), pp. e46-e215

6 V. Roger, A. Go, J. Wylie-Rossett, et al. Heart disease and stroke statistics 2011 update: a report from the American Heart Association. Circulation, 123 (2011), pp. 18-209

7 H. Bahrami, R. Kronmal, J. Lima, et al. Differences in the incidence of congestive heart failure by ethnicity: the multi-ethnic study of atherosclerosis. AMA Arch Intern Med, 168 (19) (2008), pp. 21382145

$\underline{8}$ L. Loehr, D. Rosamond, P. Change, A. Folsom, L. Chambless. Heart failure incidence and survival. Am J Cardiol, 101 (2008), pp. 1016-1022

9 S. Davis, Y. Liu, G. Gibbons. Disparities in trends of hospitalization for potentially preventable chronic conditions among African Americans during the 1990's: Implications and benchmarks. Am J Public Health, 93 (3) (2003), pp. 447-455

10 A. Go, D. Mozaffarian, V. Roger, et al. Heart disease stroke statistics 2013 update. A report from the American Heart Association. Circulation, 127 (1) (2013), pp. e6-e245

11 African-American Profile (Published 2008) Office of Minority Health Website http://www.omhrc.gov/ Accessed 01.01.14.

$\underline{12} \mathrm{E}$. Klonoff, $\mathrm{H}$. Landrine. Is skin color a marker for racial discrimination? Explain the skin color-hypertension relationship. J Behav Med, 23 (4) (2000), pp. 329-338

13 S. Manuck, A. Kasprowicz, M. Muldoon. Behaviorally-evoked cardiovascular reactivity and hypertension: conceptual issues and potential associations. Ann Behav Med, 12 (1990), pp. 17-29

14 Centers for Disease Control and Prevention. A Closer Look at African American Men and High Blood Pressure Control: A Review of Psychosocial Factors and Systems-level Interventions. U.S. Department of Health and Human Services, Atlanta, United States (2010)

15 B. McEwen. Protective and damaging effects of stress mediators: Central role of the brain. Dialogues Clin Neurosci, 8 (4) (2006), pp. 367-381

Heart \& Lung, Vol 44 (January/February 2015): pg. 33-38. DOI. This article is @ Elsevier and permission has been granted for this version to appear in e-Publications@Marquette. Elsevier does not grant permission for this article to be further copied/distributed or hosted elsewhere without the express permission from Elsevier. 
16 A. Geronimus, M. Hicken, D. Keene, J. Bound. "Weathering" and age patterns of allostatic load scores among blacks and whites in the United States. Am J Public Health, 96 (2006), pp. 826-833

17 T. Green, W. Darity Jr. Under the skin; using theories from biology and the social sciences to explore the mechanisms behind the black-white health gap. Am J Public Health, 100 (S1) (2010), pp. S36-S40

18 B. Riegel, C. Lee, V. Dickson, B. Carlson. An update on the self-care of heart failure index. J Cardiovasc Nurs, 24 (6) (2009), pp. 485-497

19 B. Riegel, D. Moser, D. Whellan, et al. State of the science: promoting selfcare in persons with heart failure: a scientific statement from the American Heart Association. Circulation, 120 (12) (2009), pp. 11411163

20 R. Gary. Self-care practices in women with diastolic heart failure. Heart Lung, 35 (1) (2006), pp. 9-19

21 K. Schnell-Hoehn, B. Naimark, R. Tate. Determinants of self-care behaviors in community-dwelling patients with heart failure. J Cardiovasc Nurs, 24 (1) (2009), pp. 40-47

22 S. Sheahan, B. Fields. Sodium dietary restriction, knowledge, beliefs, and decision-making behavior of older females. J Am Acad Nurse Pract, 20 (4) (2008), pp. 217-224

$\underline{23}$ N. Artinian, M. Magnan, M. Sloan, P. Lange. Self-care behaviors among patients with heart failure. Issues Cardiovasc Nurs, 31 (3) (2002), pp. $161-172$

24 C. Wang, M. Burris. Empowerment through photo novella: portraits of participation. Health Educ Behav, 21 (2) (1994), pp. 171-186

25 I. Ornelas, J. Amell, A. Tran, M. Royster, J. Armstrong-Brown, E. Eng. Understanding African American men's perceptions of racism, male gender socialization and social capital through photovoice. Qual Health Res, 19 (4) (April 2009), pp. 552-565

$\underline{26}$ R. Strack, C. Magill, K. McDonagh. Engaging youth through photovoice. Health Promot Pract, 5 (1) (2004), pp. 49-58

27 C. Wang, J. Cash, L. Powers. Who knows the streets as well as the homeless? Promoting personal and community action through photovoice. Health Promot Pract, 1 (1) (2000), pp. 81-89

28 Milwaukee, Wisconsin (WI) Poverty Rate Data - Information about Poor and Low Income Residents (Published 2014) CityData Website http://www.city-data.com/poverty/poverty-MilwaukeeWisconsin.html\#ixzz2uGEDwGqv Accessed 01.03.14

29 State and County Quick Facts (Published January 2014) United States Census Bureau Website http://quickfacts.census.gov/qfd/states/55/55079.html Accessed 01.03 .14

Heart \& Lung, Vol 44 (January/February 2015): pg. 33-38. DOI. This article is @ Elsevier and permission has been granted for this version to appear in e-Publications@Marquette. Elsevier does not grant permission for this article to be further copied/distributed or hosted elsewhere without the express permission from Elsevier. 
NOT THE PUBLISHED VERSION; this is the author's final, peer-reviewed manuscript. The published version may be

accessed by following the link in the citation at the bottom of the page.

30 C. Wang, W. Yi, Z. Tao, K. Carovano. Photovoice as a participatory health promotion strategy. Health Promot Int, 13 (1) (1998), pp. 75-86

31 J. Streng, S. Rhodes, G. Ayala, E. Eng, R. Arceo, S. Phipps. Realidad Latina: Latino adolescents, their school, and a university use photovoice to examine and address the influence of immigration. J Interprof Care, 18 (4) (2004), pp. 403-415

32 M. Miles, A. Huberman. Qualitative Data Analysis: An Expanded Sourcebook. Sage Publications, Thousand Oaks, California (1994)

33 G. Zimet, N. Dahlem, S. Zimet, G. Farley. Multidimensional scale of perceived social support. J Pers Assess, 52 (1) (1998), pp. 30-41

34 E. Thomas, J. Magilvy. Qualitative rigor or research validity in qualitative research. J Spec Pediatr Nurs, 16 (2011), pp. 151-155

35 S. Sayers, B. Riegel, S. Pawlowski, J. Coyne, F. Samaha. Social support and self-care of patients with heart failure. Annu Behav Med, 35 (1) (2008), pp. 70-79

36 R. Gallagher, M. Luttik, T. Jaarsma. Social support and self-care in heart failure. J Cardiovasc Nurs, 26 (6) (2011), pp. 439-445

37 K. Schnell, B. Naimark, S. McClement. Influential factors for self-care in ambulatory care heart failure patients: a qualitative perspective. Can J Cardiovasc Nurs, 16 (1) (2006), pp. 13-19

$38 \mathrm{C}$. Scotto. The lived experience of adherence for patients with heart failure. J Cardiopulm Rehabil, 25 (3) (2005), pp. 158-163

39 M. DiMatteo. Social support and patient adherence to medical treatment: a meta-analysis. Health Psychol, 23 (2) (2004), pp. 207-218

40 R. Carels. The association between disease severity, functional status, depression and daily quality of life in congestive heart failure patients. Qual Life Res, 13 (1) (2004), pp. 63-72

41 K. Falk, H. Patel, K. Swedberg, I. Ekman. Fatigue in patients with chronic heart failure-a burden associated with emotional and symptom distress. Eur J Cardiovasc Nurs, 8 (2) (2009), pp. 91-96

$\underline{42}$ K. Falk, K. Swedberg, F. Gaston-Johansson, I. Ekman. Fatigue is a prevalent and severe symptom associated with uncertainty and sense of coherence in patients with chronic heart failure. Eur J Cardiovasc Nurs, 6 (2) (2007), pp. 99-104

43 K. Glanz, J. Sallis, B. Saelens, L. Frank. Healthy nutrition environments: concepts and measures. Am J Health Promot, 19 (5) (2005), pp. 330333

I would like to thank the ten participants who allowed me to experience their lives through photographs. I would like to acknowledge Sigma Theta Tau International(HR 2179) for funding this research project. Additionally, I extend thanks to public housing authority for assisting with participant recruitment.

Heart \& Lung, Vol 44 (January/February 2015): pg. 33-38. DOI. This article is @ Elsevier and permission has been granted for this version to appear in e-Publications@Marquette. Elsevier does not grant permission for this article to be further copied/distributed or hosted elsewhere without the express permission from Elsevier. 
NOT THE PUBLISHED VERSION; this is the author's final, peer-reviewed manuscript. The published version may be accessed by following the link in the citation at the bottom of the page.

Heart \& Lung, Vol 44 (January/February 2015): pg. 33-38. DOI. This article is @ Elsevier and permission has been granted for this version to appear in e-Publications@Marquette. Elsevier does not grant permission for this article to be further copied/distributed or hosted elsewhere without the express permission from Elsevier. 